\title{
AKTIVITAS GEL MULUT BERBAHAN AKTIF EKSTRAK DAUN SIRIH HITAM KALIMANTAN SEBAGAI ANTIMIKROBA PENYEBAB RADANG GUSI (Gingivitis) DAN GIGI BERLUBANG (Caries)
}

\author{
Fajar Prasetya ${ }^{1}$ dan Angga Cipta Narsa ${ }^{2}$ \\ ${ }^{1}$ Laboratorium Farmasi Klinik, UP. Fakultas Farmasi, Universitas Mulawarman \\ Email : fajarprasetya@ farmasi.unmul.ac.id \\ ${ }^{2}$ Laboratorium Teknologi Farmasi, UP. Fakultas Farmasi, Universitas Mulawarman
}

\begin{abstract}
This study aimed to test the activity of active ingredient mouth gel preparation of kalimantan black piper betle leaf extract with the main base of Hydroxy Ethyl Cellulose namely (HEC) as a mucoadhesive polymer that is able to increase the attractive forces between the active material with a layer of mucus that will extend the contact time with the active ingredient tissue targets, moreover would be increase the effectiveness of antimicrobial activity causes inflammation of the gums (gingivitis) and tooth decay (caries). Activities that have been implemented are mouth gel activity assays with Kalimantan black piper betle leaf extract as in-vitro using the agar diffusion method pitting. In testing with active oral gel preparation of black piper betle leaf extract with the main base of Hydroxy Ethyl Cellulose namely (HEC) as in vitro, it can be seen that the sample may provide the inhibitory effect of the fungus Candida albicans and the bacterium Streptococcus mutans in the presence of a clear zone indicated on the medium. Furthermore, at this stage of the dilution of the gel in twice causing decline in the effectiveness of the inhibition of both the fungus Candida albicans and the bacterium Streptococcus mutans. The results of in-vitro testing without dilution is $19.8 \mathrm{~mm}$ in bacteria Streptococcus mutans and $34.4 \mathrm{~mm}$ in the fungus Candida albicans.
\end{abstract}

Keywords: antimicrobial, oral gel, black piper betle, gingivitis, cavities

\begin{abstract}
ABSTRAK
Penelitian ini bertujuan untuk menguji aktivitas sediaan gel mulut berbahan aktif ekstrak daun sirih hitam Kalimantan dengan basis utama yakni Hydroxy Ethyl Cellulose (HEC) sebagai mucoadhesive polymer yang mampu meningkatkan gaya tarik menarik antara bahan aktif dengan lapisan mukus sehingga akan memperpanjang waktu kontak bahan aktif dengan jaringan target, selanjutnya akan meningkatkan efektivitas aktivitas antimikroba penyebab radang gusi (gingivitis) dan gigi berlubang (caries). Kegiatan yang telah dilaksanakan adalah pengujian aktivitas gel mulut berbahan aktif ekstrak daun sirih hitam Kalimantan secara in vitro dengan menggunakan metode difusi agar teknik sumuran. Pada pengujian sediaan gel mulut berbahan aktif ekstrak daun sirih hitam Kalimantan dengan basis utama yakni Hydroxy Ethyl Cellulose (HEC) secara in vitro, dapat diketahui bahwa sampel dapat memberikan efek penghambatan jamur Candida albicans dan bakteri Streptococcus mutans dengan ditunjukkan adanya zona bening pada agar. Namun pada tahap dua kali pengenceran terhadap gel terjadi penurunan efektivitas kerja penghambatan baik pada jamur Candida albicans maupun pada bakteri Streptococcus mutans. Hasil pengujian in-vitro tanpa pengenceran adalah $19.8 \mathrm{~mm}$ pada bakteri Streptococcus mutans dan $34.4 \mathrm{~mm}$ jamur Candida albicans.
\end{abstract}

Kata kunci: antimkroba, gel mulut, sirih hitam, radang gusi, gigi berlubang 
Aktivitas Gel Mulut Berbahan Aktif Ekstrak Daun Sirih Hitam Kalimantan Sebagai Antimikroba Penyebab Radang Gusi (Gingivitis) dan Gigi Berlubang (Caries)

\section{PENDAHULUAN}

Masyarakat Indonesia sejak dulu, biasa menggunakan daun sirih sebagai penguat gigi, obat untuk menghentikan pendarahan pada gusi, menghilangkan bau mulut dan sekaligus daun sirih dikenal sebagai antiseptik alami. Secara umum dapat dilihat permasalahan terkait dengan gigi dan gusi cukup jarang terjadi pada masyarakat yang menggunakan daun sirih (nyirih) pada daerah sekitar mulut.

Penyakit karies gigi dan penyakit periodontal umumnya hampir dialami seluruh penduduk di dunia. Karies gigi dan penyakit periodental umumnya disebabkan oleh kebersihan mulut yang buruk, sehingga terjadi akumulasi plak yang mengandung berbagai macam bakteri. Selain itu plak juga merupakan penyebab utama keradangan. Kondisi ini menunjukkan bahwa penyakit gigi walaupun tidak menimbulkan kematian, tetapi dapat menurunkan produktivitas kerja (Tjahja, 2007).

Hasil Laporan Riset Kesehatan Dasar tahun 2007 menunjukkan prevalensi masalah gigi dan mulut tiap provinsi di Indonesia, yaitu lima provinsi dengan prevalensi masalah gigi dan mulut tertinggi adalah Gorontalo $33,1 \%$, Sulawesi Tengah 31,2\%, Aceh $30,5 \%$, Sulawesi Utara $29,8 \%$, dan Kalimantan Selatan 29,2\% sedangkan Kalimantan Timur menduduki peringkat ke 24 dari 33 provinsi dengan angka kejadian sebesar 21,6\%. Hal ini mengindikasikan masih rendahnya tingkat kesadaran masyarakat terhadap kesehatan gigi. Sedangkan untuk masalah karies gigi, dilaporkan bahwa karies gigi menyerang kurang lebih $72,1 \%$ penduduk Indonesia. Menurut provinsi, prevalensi karies aktif tertinggi (lebih dari 50\%) dilaporkan di Kalimantan Barat dan Sulawesi Utara $57,2 \%$, Jambi 56,1\%, Lampung 54,9\%,
Maluku 54,4\%, Yogyakarta 52,3\%, Kalimatan Timur 50,6\%, dan Sulawesi Selatan 50,4\% (Depkes RI, 2008).

Setelah dilakukan uji fitokimia, daun sirih hitam Kalimantan terbukti mengandung golongan metabolit sekunder alkaloid, karatenoid, senyawa fenolik, flavanoid, saponin, tanin, steroid, dan triterpenoid. Senyawa kimia yang diduga berfungsi sebagai antimikroba dalam hal ini adalah tanin, senyawa fenolik, saponin, flavanoid, alkaloid, dan steroid (Lemmens, 1999). Setelah dilakukan uji antimikroba, ekstrak daun sirih hitam terbukti mempunyai kemampuan dalam menghambat pertumbuhan mikroba uji Streptococcus mutans dan Candida albicans.

Berdasarkan hasil dari skrining fitokimia dan uji antimikroba tersebut, serta tujuan ingin meningkatkan efisiensi juga kenyamanan dalam pemakaian ekstrak, penulis ingin melakukan formulasi ekstrak daun sirih hitam ke dalam sediaan gel mulut, sehingga dapat menjadi produk alternatif dalam mengatasi permasalahan radang gusi (gingivitis) dan gigi berlubang (caries).

\section{METODE}

Metode yang digunakan dalam penelitian ini merupakan metode eksperimen laboratorium dengan pelaksanaan pengujian aktivitas in vitro dan in vivo sediaan gel mulut dengan basis Hydroxy Ethyl Cellulose (HEC) dan berbahan aktif ekstrak daun sirih hitam yang tumbuh di Kalimantan Timur.

\section{Bahan}

Bahan - bahan yang digunakan dalam penelitian ini adalah Hydroxy Ethyl Cellulose (HEC), Sodium meta bisulfit, gliserin, tween 80, etanol, metanol, agar, 
Aktivitas Gel Mulut Berbahan Aktif Ekstrak Daun Sirih Hitam Kalimantan Sebagai Antimikroba Penyebab Radang Gusi (Gingivitis) dan Gigi Berlubang (Caries)

pepton, ekstrak meat, PDA, infus $\mathrm{NaCl}$, biakan bakteri streptococcus mutans, biakan bakteri Candida albicans, TEA, propilen glikol, carbomer, silika gel, nheksan, etil asetat, n-butanol, menthae piperin, kelinci.

Uji efektifitas sediaan gel mulut sebagai antimikroba secara in vitro dengan metode difusi agar teknik sumuran. Metode ini dilakukan dengan membuat lubang pada medium agar yang telah diberi suspensi bakteri atau suspensi jamur. Sebanyak 20 $\mu \mathrm{L}$ sample uji diberikan pada medium agar. Pengamatan dilakukan setelah 24 jam pemberian sample pada bakteri dan 48 jam pada jamur.

Basis Gel mulut dengan berbagai konsentrasi basis yang berbeda, basis yang digunakan Hydroxy Ethyl Cellulose (HEC) dengan jumlah 2 gram.

Formula basis yang dibuat sebagai berikut :

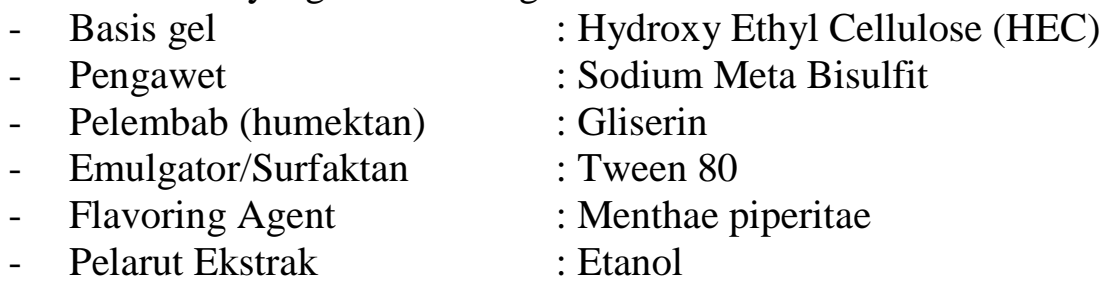

Tabel 1. Formula Sediaan Gel Mulut

\begin{tabular}{lc}
\hline Bahan & Formula \\
\hline Hydroxy Ethyl Cellulose (HEC) & 2 gram \\
Sodium Meta Bisulfit & 0.5 gram \\
Gliserin & 2 gram \\
Tween & 5 gram \\
Etanol & 10 gram \\
Menthae piperitae & 4 tetes \\
Ekstrak Daun Sirih Hitam & 0.5 gram \\
Aquadest & Ad 100 gram \\
\hline
\end{tabular}

\section{Cara pembuatan}

Dituang air $(85 \mathrm{ml})$ ke dalam gelas beker yang berisi Hydroxy Ethyl Cellulose (HEC) sementara sambil diaduk menggunakan magnetic stirer dengan kecepatan 10 rpm selama kurang lebih satu jam dilanjutkan dihidrasi selama 12 jam, kemudian setelah mengembang ditambahkan gliserin, sodium meta bisulfit sedikit demi sedikit sampai tercampur merata, kemudian ekstrak daun sirih hitam yang telah dilarutkan dalam etanol dan tween ditambah sedikit demi sedikit ke dalam gelas beker sembari diaduk diatas magnetic stirer sampai homogen. Mint flavor diteteskan pada basis yang sudah tercampur dengan ekstrak serta bahan tambahan lain dilanjutkan dengan penambahan aquades ad 100 gram sambil tetap diaduk menggunakan magnetic stirer hingga didapatkan masa gel yang homogen. 
Aktivitas Gel Mulut Berbahan Aktif Ekstrak Daun Sirih Hitam Kalimantan Sebagai Antimikroba Penyebab Radang Gusi (Gingivitis) dan Gigi Berlubang (Caries)

\section{HASIL DAN PEMBAHASAN}

Fokus penelitian Formulasi Gel Mulut Berbahan Aktif Ekstrak Daun Sirih Hitam Sebagai Antimikroba Penyebab Radang Gusi (Gingivitis) dan Gigi Berlubang (Caries) pada tahun kedua ini adalah melakukan pengujian aktivitas in vitro sediaan gel mulut dengan basis Hydroxy Ethyl Cellulose (HEC) dan berbahan aktif ekstrak daun sirih hitam yang tumbuh di Kalimantan Timur. Formula yang digunakan pada penelitian ini adalah penggunaan Hydroxy Ethyl Cellulose (HEC) sebanyak 2 gram. Pemilihan basis sediaan gel mulut tersebut mampu melakukan kontak dalam waktu lama secara lokal yakni di daerah gigi dan gusi dimana target aksi sediaan ini diharapkan. Basis gel mulut yang optimal disini dievaluasi berdasarkan evaluasi karakteristik dan stabilitasnya dari beberapa parameter yang meliputi organoleptis, viskositas, $\mathrm{pH}$, daya sebar, konsistensi (bleeding) dari sediaan. Jumlah kandungan ekstrak daun sirih hitam yang digunakan pada pembuatan gel mulut sebagai antimikroba penyebab radang gusi (gingivitis) dan gigi berlubang (caries) tidak menggunakan hasil konsentrasi efektif yang didapatkan pada uji aktivitas antimikroba secara in vitro yakni pada fraksi n-heksan dengan konsentrasi 20\%, dimana rata-rata diameter zona bunuhnya sebesar 23,24 $\mathrm{mm}$, tetapi menggunakan konsentrasi $0.5 \%$ dari ekstrak methanol karena didapatkan zona bunuh yang cukup baik yakni $10.7 \mathrm{~mm}$ untuk Streptococcus mutans dan $11.7 \mathrm{~mm}$ untuk Candida albicans, sehingga penampilan gel terutama warna, rasa, dan bau menjadi lebih baik pada sediaan gel.

Pengujian menggunakan metode difusi agar teknik sumuran. Metode ini dilakukan dengan membuat lubang pada medium agar yang telah diberi suspensi bakteri atau suspensi jamur. Sebanyak $20 \mu \mathrm{L}$ sample uji diberikan pada medium agar. Pengamatan dilakukan setelah 24 jam pemberian sampel pada bakteri dan 48 jam pada jamur.Adapun hasil pengujian dapat dilihat pada Tabel 2.

Tabel 2. Hasil Pengujian antimikroba gel gel mulut berbahan aktif ekstrak daun sirih hitam berbasis Hydroxyl Ethyl Celulose (HEC)

\begin{tabular}{ccccc}
\hline \multirow{2}{*}{ Mikroba } & \multicolumn{4}{c}{ Zona bening $(\mathrm{mm})$} \\
\cline { 2 - 5 } & \multirow{3}{*}{ Tanpa pengenceran } & $2 \mathrm{x}$ & $4 \mathrm{x}$ & $5 \mathrm{x}$ \\
\cline { 2 - 5 } Candida & 20 & 9 & - & - \\
albicans & 20 & 8 & - & - \\
& 20 & 10 & - & - \\
& 20 & 10 & - & - \\
Streptococcus & 19 & 15 & - & - \\
mutans & 35 & 14 & 12 & - \\
& 35 & 15 & 12 & - \\
& 35 & 14 & 11,5 & - \\
& 35 & 14 & 12 & - \\
\hline
\end{tabular}


Hasilnya dapat diketahui bahwa sampel dapat memberikan efek penghambatan dengan ditunjukkan adanya zona bening pada agar. Namun pada tahap pengenceran dua kali terjadi penurunan efektivitas kerja penghambatan baik pada jamur Candida albicans maupun pada bakteri Streptococcus mutans, hal ini mengungkapkan bahwa formula gel mulut berbahan aktif ekstrak daun sirih hitam dan berbasis Hydroxyl Ethyl Celulose (HEC) memiliki viskositas serta kemampuan berdifusi yang efektif dalam menghantarkan bahan aktif yakni ekstrak daun sirih hitam agar dapat beraktivitas kepada mikroba pada medium dan selanjutnya mampu berpenetrasi kedalam mikroba Candida albicans maupun pada bakteri Streptococcus mutans. Berdasarkan data pengujian yang didapat pada Tabel 2 maka dapat dikatakan sediaan gel mulut berbahan aktif ekstrak daun sirih hitam dan berbasis Hydroxyl Ethyl Celulose (HEC) mempunyai aktivitas sebagai antimikroba penyebab radang gusi (gingivitis) dan gigi berlubang (caries) yang lebih baik dibandingkan dengan ekstrak kasar. Fenomena ini dikarenakan pada formula gel mulut ini mengandung Sodium Meta Bisulfit dan etanol yang juga mempunyai aktivitas sebagai antimikroba.

Berdasarkan diameter zona bening yang didapatkan dari pengujian maka aktivitas antimikroba gel mulut berbahan aktif ekstrak daun sirih hitam dan berbasis Hydroxyl Ethyl Celulose (HEC) memiliki kategori sangat kuat. Suatu antimikroba dikatakan mempunyai aktivitas terhadap mikroba jika mempunyai kekuatan sebagai berikut, luas daerah hambatan $20 \mathrm{~mm}$ atau lebih masuk kategori sangat kuat, daerah hambatan Antara 10 - $20 \mathrm{~mm}$ masuk kategori kuat, daerah hambatan 5-10 mm masuk kategori sedang dan daerah hambatan $5 \mathrm{~mm}$ atau kurang masuk kategori lemah.

Aktivitas antibakteri diduga karena adanya kandungan senyawa alkaloid, saponin, dan flavonoid yang terdeteksi di dalam ekstrak. Beberapa saponin bekerja sebagai antimikroba. Selain itu, saponin memiliki aktivitas sitotoksik atau aktivitas antitumor. Saponin memiliki tegangan permukaan yang kuat sehingga dapat menimbulkan busa jika dikocok dalam air dan pada konsentrasi yang rendah sering menyebabkan hemolisis sel, senyawa ini akan terkonsentrasi pada selaput sel (membran sel) dan mengganggu stabilitas membran sel sehingga sel dapat mengalami lisis. Mekanisme kerja senyawa flavonoid diduga bekerja dengan cara mendenaturasi protein sel bakteri yang berakibat pada kerusakan membran sel yang tidak dapat diperbaiki lagi sehingga menyebabkan kematian sel.

\section{KESIMPULAN}

Gel mulut berbahan aktif ekstrak daun sirih hitam Kalimantan memiliki aktivitas antimikroba pada pengujian secara in vitro dengan luas zona hambat $19.8 \mathrm{~mm}$ pada bakteri Streptococcus mutans dan $34.4 \mathrm{~mm}$ jamur Candida albicans.

\section{UCAPAN TERIMA KASIH}

Terimakasih kepada DIKTI melewati Lembaga Penelitian UNMUL dan UP. Fakultas Farmasi Universitas Mulawarman serta Laboratorium Farmakologi Fakultas Farmasi ITB. 
Aktivitas Gel Mulut Berbahan Aktif Ekstrak Daun Sirih Hitam Kalimantan Sebagai Antimikroba Penyebab Radang Gusi (Gingivitis) dan Gigi Berlubang (Caries)

\section{DAFTAR PUSTAKA}

1. Depkes RI. 2008. Laporan Hasil Riset Kesehatan Dasar (RISKESDAS) Nasional 2007. Badan Penelitian dan Pengembangan Kesehatan: Jakarta.
2. Tjahja I. 2007. Status Kesehatan Gigi dan Mulut Ditinjau dari Faktor Individu Pengunjung Puskesmas DKI Jakarta Tahun 2007. Pusat Penelitian dan Pengembangan Biomedis: Jakarta. 